\title{
ANALISIS SISTEM LEMBAGA KEUANGAN SYARIAH DAN LEMBAGA KEUANGAN KONVENSIONAL
}

\author{
Roifatus Syauqoti \\ Mohammad Ghozali \\ Fakultas Syariah dan Pasca Sarjana \\ Program Studi Hukum Ekonomi Syariah \\ Universitas Darussalam Gontor, \\ roifatussyauqi@gmail.com \\ mohammadghozali@unida.gontor.ac.id
}

\begin{abstract}
For holding the banking system, Indonesia applied dual banking system based on institutional regulation Number 10, 1998. The existence of dual banking system was realized by monetary crisis on 1998, that caused bankrupt impact of conventional banking system for the high ratio of the debt interest. Dual banking system means that Indonesia applied both sharia and conventional banking system. For this matter we use qualitative method and analysis descriptive method, by describing and analyzing sharia financial foundation and conventional financial foundation system. both are same in money receiving technic, transfer mechanism, computer technology, and general terms to obtain the credit. Both sharia financial foundation and conventional financial foundation have more differences. The main different between them is in the profit gaining system obtain. Sharia bank applied profit sharing system which is oriented for blessed life here and the day after, in other case conventional bank applied interest system which is oriented for gaining profit as much as possible in this world. Moreover, sharia bank is watched by the sharia supervising council, in order to revive the pure sharia, not same as conventional bank.
\end{abstract}

Keywords: Banking system, Conventional Bank, Sharia Bank

\section{PENDAHULUAN}

Perkembangan ekonomi di Indonesia salah satunya dapat dilihat melalui munculnya lembaga-lembaga keuangan terutama pada sektor perbankan. Pada awal perkembangannya lembaga-lembaga keuangan yang ada di Indonesia berbasis konvensional yang bersistem bunga dengan orientasi mendapatkan keuntungan sebanyak-banyaknya. Sistem bunga inilah yang menjadi sebab melemahnya perbankan pada krisis moneter 
tahun 1998. Bank-bank konvensional mulai bangkrut karena tingginya suku bunga pinjaman.

Fenomena bangkrutnya bank konvensional ini tidak berlaku bagi pelaku usaha yang menggunakan dana dari bank syariah. Para pengusaha yang menggunakan jasa di bank syariah tidak perlu membayar bunga hingga puluhan persen karena bank syariah menggunakan sistem bagi hasil, bukan bunga. Fenomena inilah yang akhirnya menjadikan bank syariah sorotan bagi masyarakat yang ingin terhindar dari bunga yang sejatinya merugikan.

Sistem perbankan syariah di Indonesia dimulai pada tahun 1992 dengan berasaskan pada UU No. 7 Tahun 1992 yang memungkinkan bank menjalankan bisnisnya dengan sistem bagi hasil. Bank syariah yang pertama di Indonesia adalah Bank Syariah Muamalat Indonesia (BMI). Setelah diluncurkan dan diberlakukan Dual Banking System melalui UU No. 10 Tahun 1998. Setelah adanya Undang-undang ini bank syariah

\section{METODE KAJIAN}

Metode kajian yang digunakan adalah metode kajian kualitatif, kajian ini bersifat deskriptif analitik, hal ini untuk mendeskripsikan dan menganalisis sistem lembaga keuangan syariah dengan sistem lembaga keuangan konvensional. Tulisan ini akan menawarkan tentang perbedaan antara lembaga keuangan syariah dan lembaga keuangan konvensional.

\section{Pengertian Lembaga Keuangan Konvensional}

Lembaga Keuangan dapat didefinisikan sebagai suatu badan usaha yang aset utamanya berbentuk aset keuangan maupun tagihan-tagihan yang dapat berupa saham, obligasi, dan pinjaman, daripada berbentuk aktiva riil seperti bangunan, perlengkapan dan bahan baku. Sedangkan menurut Undang-undang Nomor 14 Tahun 1967 tentang Pokok-pokok Perbankan, yang dimaksud lembaga keuangan adalah semua badan yang melalui kegiatan-kegiatan di bidang keuangan menarik uang dari masyarakat dan menyalurkan uang tersebut kembali ke masyarakat. Dari pengertian di atas diketahui bahwa lembaga keuangan adalah tempat transformasi atau perpindahan dana dari pihak yang mengalami kelebihan dana (surplus of funds) kepada pihak yang mengalami kekurangan dana (deficit of funds). 


\section{Bentuk Lembaga Keuangan Konvensional}

Bentuk Lembaga Keuangan pada garis besarnya dapat dibedakan menjadi 2. yaitu Lembaga Keuangan Bank dan Non-Bank. Keduanya memiliki fungsi dan kelembagaan yang berbeda.

1. Lembaga Keuangan Bank (depositori)

Pengertian bank menurut Undang-undang No. 10 Tahun 1998 adalah badan usaha yang menghimpun dana dari masyarakat dalam bentuk simpanan dan menyalurkannya kepada masyarakat dalam bentuk kredit dan atau bentuk-bentuk lainnya dalam rangka meningkatkan taraf hidup rakyat banyak.

Tata Perbankan di Indonesia:

a. Bank Sentral (Central Bank)

Adalah bank milik pemerintah yang bertugas mengatur, menjaga, dan memelihara kestabilan nilai mata uang negaranya, membimbing pelaksanaan kebijakan moneter, serta mengkoordinasi, membina, dan mengawasi semua perbankan.

b. Bank Umum (Comercial Bank)

adalah lembaga yang menjalankan usaha secara konvensional yang dalam kegiatannya memberikan jasa dalam lalu lintas pembayaran.

Struktur perbankan di Indonesia terdiri atas BU (Bank Umum) dan BPR (Bank Perkreditan Rakyat). Perbedaan antara keduanya adalah dalam hal kegiatan operasionalnya. BPR tidak dapat menciptakan uang giral dan memiliki jangkauan dan kegiatan operasional yang terbatas.

Fungsi-fungsi utama bank adalah:

a. Menghimpun dana masyarakat dalam bentuk simpanan.

b. Menyalurkan dana ke masyarakat dalam bentuk kredit.

c. Melancarkan transaksi perdagangan dan peredaran uang.

2. Lembaga Keuangan Non-Bank (nondepositori)

Lembaga Keuangan Non-Bank adalah badan usaha yang melakukan kegiatan di bidang keuangan, secara langsung ataupun tidak langsung, menghimpun dana dari masyarakat dan menyalurkan kembali kepada masyarakat untuk kegiatan produktif. Kegiatan Lembaga Keuangan NonBank difokuskan pada salah satu kegiatan keuangan saja. 
Bentuk-bentuk Lembaga Keuangan Non-Bank di Indonesia:

a. Modal ventura

Modal ventura adalah badan usaha yang melakukan usaha pembiayaan dalam bentuk penyertaan modal dalam suatu perusahaan yang menerima bantuan pembiayaan untuk jangka waktu tertentu.

b. Anjak piutang

Anjak piutang adalah badan usaha yang melakukan kegiatan pembiayaan dalam bentuk pembelian dan atau pengalihan serta pengurusan piutang dan tagihan jangka pendek suatu perusahaan (debitur) dari transaksi perdagangan di dalam atau di luar negeri.

c. Asuransi

Asuransi adalah perjanjian antara dua pihak atau lebih, dimana pihak penanggung mengikatkan diri kepada tertanggung, dengan menerima premi asuransi untuk memberikan penggantian kepada tertanggung karena kerugian, kerusakan, atau kehilangan keuntungan yang diharapkan. Atau tanggung jawab hukum kepada pihak ketiga yang mungkin akan diderita tertanggung, yang timbul dari suatu perinstiwa yang tidak pasti, atau untuk memberikan suatu pembayaran yang didasarkan atas meninggal atau hidupnya seseorang yang dipertanggungkan.

d. Dana pensiun

Dana pensiun merupaka suatu lembaga atau badan hukum yang mengelola program pensiun dengan tujuan untuk memberikan kesejahteraan kepada karyawan suatu perusahaan terutama yang telah pensiun.

e. Pegadaian

Pegadaian adalah lembaga yang memberikan pinjaman kepada masyarakat dengan menahan suatu barang sebagai jaminan pinjaman.

f. Pasar Modal

Pasar Modal adalah pasar yang memperjualbelikan berbagai instrumen keuangan (sekuritas) jangka panjang, baik dalam bentuk utang maupun modal sendiri yang diterbitkan oleh perusahaan swasta.

g. Pasar uang

Pasar Uang adalah sarana yang menyediakan pembiayaan jangka pendek (kurang dari 1 tahun), pasar uang tidak mempunyai tempat fisik seperti pasar modal. 


\section{h. Reksadana}

Reksa Dana adalah wadah yang dipergunakan untuk menghimpun dana dari masyarakat pemodal untuk selanjutnya diinvestasikan dalam portofolio efek oleh manajer investasi. Portofolio efek seperti saham, obligasi, instrument pasar uang, deposito, uang kas dll.

\section{Lembaga Keuangan Syariah}

Pengertian Lembaga Keuangan Syariah tidak memiliki banyak perbedaan dengan Lembaga Keuangan Konvensional, hanya saja dalam Lembaga Keuangan Syariah memiliki prinsip yang tidak sama dengan Lembaga Keuangan Konvensional yaitu prinsip hukum Islam dalam kegiatan perbankan dan keuangan berdasarkan fatwa yang dikeluarkan oleh lembaga yang memiliki kewenangan dalam penetapan fatwa di bidang syariah.

\section{Bentuk Lembaga Keuangan Syariah}

Bentuk Lembaga Keuangan Syariah sebagaimana yang ada pada Lembaga Keuangan Konvensional dapat dibedakan menjadi 2, yaitu Lembaga Keuangan Syariah Bank (Bank syariah) dan Lembaga Keuangan Syariah NonBank.

\section{Bank Syariah}

Bank syariah adalah bank yang menjalankan kegiatan usahanya berdasarkan prinsip syariah. Secara filosofis bank syariah adalah bank yang aktivitasnya meninggalkan masalah riba. Menurut jenisnya terdiri dari BUS (Bank Umum Syariah) dan BPRS (Bank Pembiayaan Rakyat Syariah). Bank syariah memiliki sistem yang berbeda sengan bank konvensional. Bank syariah memberikan layanan bebas bunga pada nasabahnya. Bank syariah tidak menggunakan sistem bunga, baik bunga pada nasabah penyimpan dana maupun nasabah peminjam dana.

Falsafah ekonomi syariah sebagai landasan filosofis perbankan syariah. 


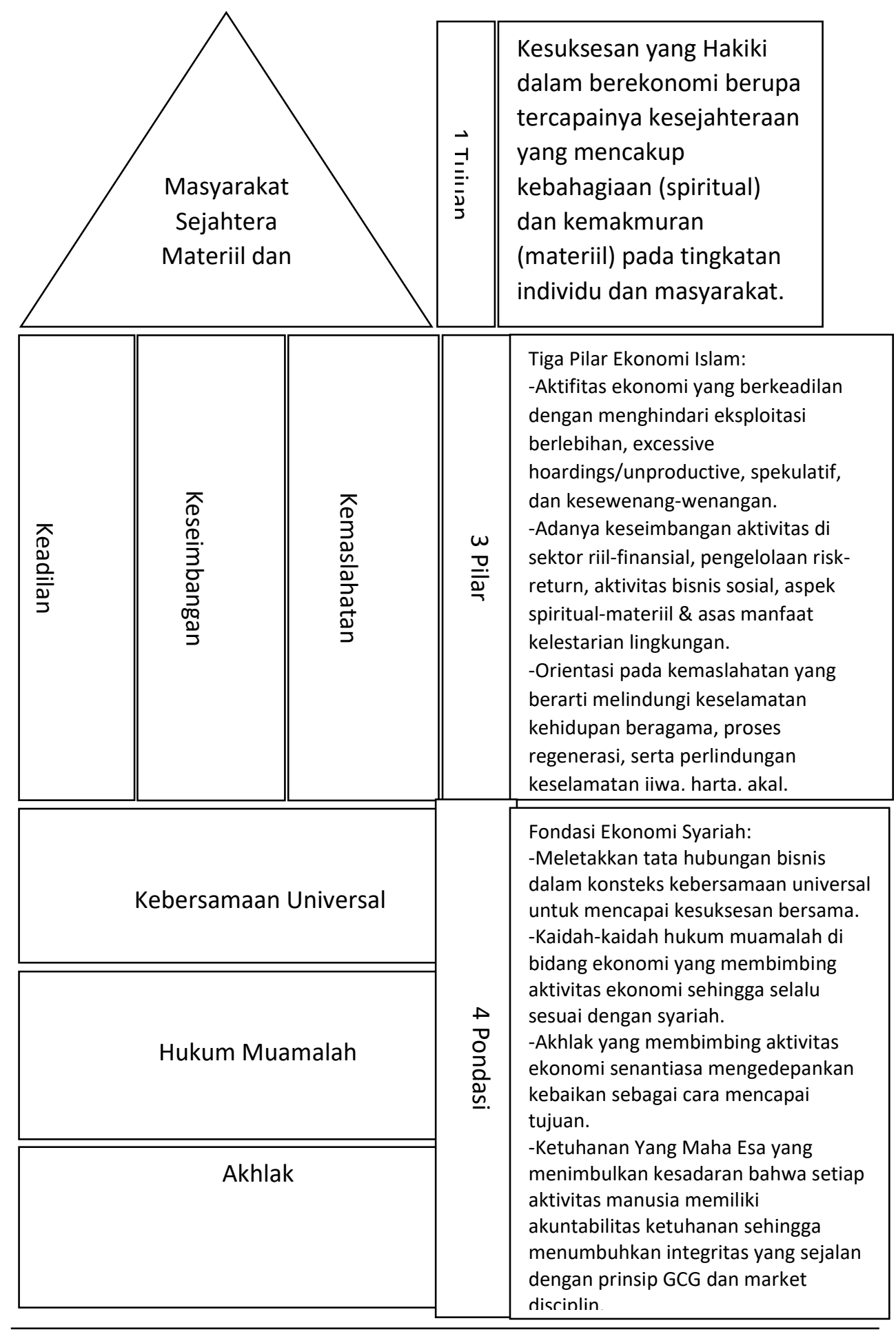

20 | IQTISHODUNA Vol. 14 No. 1 Tahun 2018 
Prinsip-prinsip pembiayaan di lembaga keuangan syariah:

a. Tidak ada transaksi keuangan berbasis bunga (riba)

b. Pengenalan pajak religius atau pemberian sedekah, zakat

c. Pelarangan produksi barang dan jasa yang bertentangan dengan hukum Islam (haram)

d. Penghindaran aktivitas ekonomi yang melibatkan maysir (judi) gharar (transaksi yang tidak jelas)

e. Penyediaan takaful (asuransi Islam)

Prinsip-prinsip dasar perbankan syariah:

a. Titipan atau simpanan (Al-Wadi'ah)

Al-Wadi'ah adalah harta yang ditinggalkan kepada pihak yang lain dengan sengaja untuk dijaga tanpa memberikan imbalan. Pengertian lain dari al-wadi'ah adalah perjanjian simpan menyimpan atau penitipan barang berharga antara pihak yang mempunyai barang dan pihak yang diberik kepercayaan.

b. Bagi Hasil

Dalam prinsip bagi hasil dibagi menjadi beberapa prinsip, yaitu:

1) Mudharabah

Mudharabah adalah akad kerjasama antara 2 pihak, dimana modal berasal dari salah satu pihak (shahibul maal) dan pengelolaan oleh pihak lainnya (mudharib). Keuntungan dibagi sesuai kesepakatan, adapun kerugian ditanggung oleh shahibul maal.

Jenis-jenis mudharabah:

a) Mudharabah Muthlaqah

b) Mudharabah Muqayyadah

2) Musyarakah

Musyarakah adalah perjanjian kerjasama antara dua pihak atau lebih untuk melakukan suatu usaha tertentu, dan masing-masing memberikan kontribusi modal. Keuntungan dan kerugian akan ditanggung bersama sesuai dengan proporsi yang telah disepakati di awal. Jenis-jenis musyarakah:

a) Musyarakah pemilikan

b) Musyarakah akad 
3) Muzara'ah

Muzara'ah adalah kerjasama antara 2 pihak dalam pengelolaan tanah antara pemilik lahan dan penggarap, dimana benih berasal dari pemilik lahan. Muzara'ah dalam pelaksanaannya seperti mudharabah hanya saja muzara'ah dalam bidang pertanian.

4) Mukhabarah

Mukhabarah adalah akad kerjasama antara 2 pihak dalam pengelolaan tanah antara pemilik lahan dan penggarap, perbedaannya dengan muzara'ah adalah benih dalam mukhabarah dari pengelola.

c. Jual Beli

1) Murabahah

Murabahah adalah jual beli barang dengan menjelaskan harga asalnya dengan tambahan keuntungan yang disepakati.

2) Salam

Salam adalah akad jual beli yang sifat penyerahan barangnya di kemudian dari dengan pembayaran dilakukan di muka atau di majlis akad.

3) Istishna'

Istishna' adalah akad jual beli dimana pembeli meminta pembuat barang untuk membuat barang sesuai keinginan pembeli.

d. Sewa (Ijarah)

Ijarah adalah akad atas manfaat yang diperbolehkan dengan jangka waktu dan imbalan yang diketahui dan disepakati oleh pihak yang berakad, Ijarah merupakan salah satu bentuk dari jual beli karena Ijarah pada hakikatnya adalah jual beli manfaat.

e. Jasa

\section{1) Wakalah}

Wakalah adalah pelimpahan kekuasaan oleh seseorang pada orang lain dalam hal-hal yang diperbolehkan dan diketahui oleh dua belah pihak.

2) Kafalah

Kafalah adalah jaminan yang diberikan oleh penanggung kepada pihak ketiga atas pemenuhan kewajiban atau tanggung jawab pihak kedua (yang ditanggung). 
3) Hawalah

Hawalah adalah pengalihan hutang dari orang yang berhutang kepada yang menganggung hutangnya.

4) Rahn

Rahn adalah menahan salah satu harta milik si peminjam sebagai jaminan atas pinjaman yang diterimanya atau dapat disebut sebagai pegadaian. Harta yang ditahan boleh seharga atau lebih sedikit atau lebih banyak dari jumlah pinjaman.

5) Qardh

Qardh adalah pemberian harta kepada orang lain yang dapat ditagih dan diminta kembali, dengan kata lain qardh adalah pinjaman tanpa mengharapkan imbalan.

2. Lembaga Keuangan Syariah Non-Bank

Lembaga-lembaga keuangan syariah non-bank jenis-jenisnya tidak jauh berbeda dengan lembaga-lembaga keuangan konvensional. Hanya ada 1 lembaga yang dimiliki bank syariah namun tidak dimiliki bank konvensional, lembaga tersebut adalah BMT atau Baitul Maal wat Tamwil. BMT terdiri dari 2 istilah yaitu baitul maal dan baitut tamwil. Baitul maal dalam lebih mengarah pada usaha pengumpulan dan penyaluran dana yang non-profit seperti zakat, infaq dan shodaqoh. Sedangkan baitut tamwil lebih pada pengumpulan dan penyaluran dana komersial.

\section{Perbandingan Sistem Lembaga Keuangan Syariah dan Lembaga Keuangan Konvensional}

\begin{tabular}{|l|l|l|l|}
\hline No & Variabel & $\begin{array}{l}\text { Lembaga Keuangan } \\
\text { Syariah }\end{array}$ & $\begin{array}{l}\text { Lembaga Keuangan } \\
\text { Konvensional }\end{array}$ \\
\hline 1 & Investasi & $\begin{array}{l}\text { Investasi hanya untuk } \\
\text { proyek dan produk yang } \\
\text { halal serta } \\
\text { menguntungkan }\end{array}$ & $\begin{array}{l}\text { Investasi, } \\
\text { mempertimbangkan } \\
\text { halal atau haram proyek } \\
\text { yang di biayai } \\
\text { menguntungkan }\end{array}$ \\
\hline 2 & Return & $\begin{array}{l}\text { Return yang dibayar } \\
\text { dan/atau diterima } \\
\text { berasal dari bagi hasil } \\
\text { atau pendapatan lainnya }\end{array}$ & $\begin{array}{l}\text { Return baik yang dibayar } \\
\text { kepada nasabah } \\
\text { penyimpan dana dan } \\
\text { return yang diterima dari }\end{array}$ \\
\hline
\end{tabular}


Roifatus Syauqoti, Mohammad Ghozali

\begin{tabular}{|c|c|c|c|}
\hline & & $\begin{array}{l}\text { berdasarkan prinsip } \\
\text { syariah }\end{array}$ & $\begin{array}{l}\text { nasabah pengguna dana } \\
\text { berupa bunga }\end{array}$ \\
\hline 3 & Perjanjian & $\begin{array}{l}\text { Perjanjian dibuat dalam } \\
\text { bentuk akad sesuai } \\
\text { dengan syariah Islam }\end{array}$ & $\begin{array}{l}\text { Perjanjian menggunakan } \\
\text { hukum positif }\end{array}$ \\
\hline 4 & $\begin{array}{l}\text { Orientasi } \\
\text { pembiayaan }\end{array}$ & $\begin{array}{ll} & \text { Orientasi pembiayaan, } \\
\text { tidak hanya untuk } & \\
\text { keuntungan akan tetapi } \\
\text { falah oriented, yaitu } \\
\text { berorientasi } \\
\text { kesejahteraan } \\
\text { masyarakat }\end{array}$ & $\begin{array}{lr}\text { Orientasi } & \text { pembiayaan, } \\
\text { untuk } & \text { memperoleh } \\
\text { kentungan atas dana } \\
\text { yang dipinjamkan. }\end{array}$ \\
\hline 5 & $\begin{array}{l}\text { Hubungan } \\
\text { antara } \\
\text { nasabah dan } \\
\text { bank }\end{array}$ & $\begin{array}{lr}\begin{array}{l}\text { Hubungan } \\
\text { nasabah dan }\end{array} & \text { bank } \\
\text { adalah mitra } & \end{array}$ & $\begin{array}{l}\text { Hubungan antara bank } \\
\text { dan nasabah adalah } \\
\text { kreditur dan debitur }\end{array}$ \\
\hline 6 & Pengawasan & \begin{tabular}{lr}
\multicolumn{2}{l}{ Dewan pengawas terdiri } \\
dari BI, OJK, & Bapepam, \\
Komisaris, & Dewan \\
Syariah & Nasional dan \\
Dewan & Pengawas \\
Syariah & \\
\end{tabular} & $\begin{array}{l}\text { Dewan pengawas terdiri } \\
\text { dari BI, Bapepam, dan } \\
\text { Komisaris }\end{array}$ \\
\hline 7 & $\begin{array}{l}\text { Penyelesaian } \\
\text { Sengketa }\end{array}$ & $\begin{array}{l}\text { Penyelesaian sengketa } \\
\text { diupayakan } \\
\text { penyelesaiaannya secara } \\
\text { musyawarah antara } \\
\text { bank dan nasabah } \\
\text { melalui Badan Arbitrase } \\
\text { Syariah Nasional dan } \\
\text { Peradilan Agama }\end{array}$ & $\begin{array}{l}\text { Penyelesaian sengketa } \\
\text { melalui pengadilan } \\
\text { negeri setempat }\end{array}$ \\
\hline
\end{tabular}

Sumber : Disadur dari Ismail, Perbankan Syariah

Analisis perbedaan bank syariah dan bank konvensional:

1. Investasi

Dalam mencari keuntungan Islam tidak melarang untuk mendapatkan keuntungan yang sebanyak-banyaknya, hanya saja 
Islam membatasi cara untuk mendapatkan keuntungan tersebut. Maka perbankan syariah juga membatasi dalam hal investasi, hanya berinvestasi pada usaha-usaha yang halal dan juga menguntungkan. Sedangkan perbankan konvensional tidak mengenal batasan dalam mendapatkan keuntungan. Mereka berinvestasi pada usaha apapun yang menguntungkan seperti pada perusahaan-perusahaan minuman keras.

2. Return

Pemberian return di bank syariah dengan menggunakan prinsip bagi hasil. Jumlah yang didapatkan dalam bagi hasil berdasarkan prosentasi yang sudah disepakati dalam akad. Mekanisme bagi hasil yang diterapkan di bank syariah terdiri dari dua sistem yaitu profit sharing dan revenue sharing. Sedangkan bank konvensional dalam membagikan return kepada nasabah penyimpan dana dengan bunga yang didapatkan dari nasabah peminjam dana. Prosentase bunga peminjam dana lebih besar dari prosentasi bunga bagi penyimpan dana.

3. Perjanjian

Perjanjian dalam bank syariah menggunakan akad-akad yang sudah diatur dalam fiqih. Akad yang dilakukan memiliki konsekuensi duniawi dan ukhrawi karena akad yang dilakukan berdasarkan dengan hukum Islam. Sedangkan bank konvensional dalam melakukan perjanjiannya dengan asas hukum positif.

4. Orientasi pembiayaan

Bank syariah dalam menyalurkan dana berorientasi pada pendapatan keuntungan sebagaimana bank konvensional nanum yang membedakan antara keduanya adalah orientasi bank syariah tidak terbatas hanya mendapatkan keuntungan duniawi melainkan dengan bertransaksi dengan bank syariah akan menghindarkan dari bunga yang haram dan menciptakan kebahagiaan akhirat.

5. Hubungan antara nasabah dan bank

Hubungan bank syariah dengan nasabah pengguna dana adalah kemitraan keduanya memiliki kedudukan yang sama, sehingga hasil usaha atas kerjasama yang dilakukan oleh nasabah pengguna dana, akan dibagi hasilkan dengan bank syariah dengan nisbah yang sudah disepakati. Sedangkan dalam bank konvensional nasabah peminjam 
dana sebagai kreditur yang dikenakan bunga sangat tinggi dalam pengembalian pinjamannya.

6. Pengawasan

Dalam menjalankan usahanya perbankan syariah maupun perbankan konvensional diawasi oleh BI, OJK dan Komisaris setiap bank masingmasing. Yang membedakan adalah bank syariah dalam pelaksanaannya diawasi oleh Dewan Pengawas Syariah (DPS). Tugas utama dari DPS adalah mengawasi kegiatan usaha bank agar tidak menyimpang dari ketentuan dan prinsip syariah yang telah difatwakan oleh Dewan Syariah Nasional (DSN).

7. Penyelesaian Sengketa

Permasalahan dalam bank syariah diselesaikan dengan cara yang lebih kekeluargaan yaitu dengan bermusyawarah. Namun, jika tidak menemukan titik temu maka sengketa ini dapat diselesaikan dengan 2 cara yaitu diselesaikan di Badan Arbitrase Syariah Nasional (Basyarnas) atau di Peradilan Agama. Sedangkan bank konvensional apabila ada sengketa dengan nasabah maka sengketa akan diangkat di peradilan negeri.

\section{KESIMPULAN}

Lembaga Keuangan Konvensional dan Lembaga Keuangan Syariah memiliki beberapa persamaan dan perbedaan. Persamaan antara keduanya ada pada teknis penerimaan uang, mekanisme transfer, tekbologi komputer, syarat-syarat umum memperoleh pembiayaan seperti KTP, NPWP, proposal, laporan keuangan dan sebagainya. Perbedaan antara keduanya adalah pada aspek investasi, dimana bank syariah membatasi investasinya pada usaha yang halal saja. Pada aspek return bank syariah menggunakan sistem bagi hasil dan bank konvensional dengan sistem bunga. Dalam aspek perjanjian, bank syariah menggunakan akad yang sesuai dengan hukum Islam sedangkan bank konvensional berasaskan hukum positif. Orientasi bank syariah adalah profit and falah oriented sedangkan bank konvensional hanya pada profit oriented. Hubungan antara nasabah dan bank syariah lebih pada hubungan antar mitra bukan kreditur dan debitur. Dalam operasionalnya bank syariah diawasi oleh DPS untuk menjaga kesyariaahan suatu bank. Jika ada sengketa antara bank dan nasabah diselesaikan secara kekeluargaan jika terpaksa, maka sengketa diajukan pada basyarnas atau peradilan agama, sedangkan sengketa pada bank konvensional diangkat di peradilan negeri. 


\section{DAFTAR PUSTAKA}

'Abidin, Muhammad. Raddu Al-Muhtar. Dar Al-Muhtar Al-'Alamah.

Ad-Dibyan, Ali bin Rasyid. 1429 H. Al-Mu'awadhah 'ala Al-Kafalah. Saudi. Jami'ah Al-Mulk.

Al-Asyqar, Muhammad Sulaiman Abdullah. 1998. Al-Mujalla fi Al-Fiqhi AlHanbali. Cet-I. Jeddah. Dar Al-Basyir.

Al-Jaa'udi, Abdur Rahman bin 'Utsman. 1429. Al-Ijarah bi Juz'in min Al-'Amal. Saudi. Jamiatu Al-Malik.

Al-Muqadasi, Syamsuddin Muhammad bin Muflih. 2003. Al-Furu'. Cet- I. Beirut. Muassatu Ar-Risalah.

Al-Qurthubi, Muhammad bin Ahmad bin Muhammad bin Ahmad bin Rusydi. 1982. Bidayatul Mujtahid wa Nihayatul Muqtashid. Cet-VI. Beirut. DarAl-Ma'rifah.

Anggadini, Sri Dewi. "Mekanisme Pengawasan Dewan Pengawas Syariah dan Bank Indonesia Terhadap Bank Syariah". Majalah Ilmiah UNIKOM. Vol. 12 No. 1

Antonio, Muhammad Syafi'i. 2001. Bank Syariah dari Teori ke Praktik. Cet-I. Jakarta. Gema Insani Press.

Arief, Suyoto. Januari 2014. "Bank Islam Sebuah Alternatif Terhadap Sistem Bunga”. Jurnal Ekonomi Islam. Institut Studi Islam Darussalam, Vol. 2. No. 1.

As-Sarhisi, Syamsuddin. Al-Mabshuth. Beirut. Dar Al-Ma'rifah.

Asy-Syarbini, Syamsuddin Muhammad bin Al-Khotiib. 1997.Mughni Muhtaj. Beirut. Dar Al-Ma'rifah.

Asy-Syaruni, Abdul Al-Hamiid. Hawasyi Tuhfatu Al-Muhtaj bi Syarhi AlManhaj. Kairo. Mathba'ah Mushtofa Ahmad.

Hammad, Nazih. 2008. Mu'jam Al-Mustholahat Al-Maliyah wa Al-Iqtishadiyyah fi Lughati Al-Fuqaha. Cet-I. Damaskus. Dar Al-Qolam

Hosen, Nadratuzzaman. 2007. Menjawab Keraguan Umat Islam Terhadap Bank Syariah. Cet-I. Jakarta. pkes publishing.

Huda, Nurul. Mohamad Heykal. 2015. Lembaga Keuangan Islam. Cet-3. Jakarta. Prenadamedia Group.

Ikatan Bankir Indonesia. 2014. Mengelola Bank Syariah. Jakarta. PT Gramedia Pustaka Utama. 
Imaarah, Muhammad. 1993. Kamus Al-Mustholahat fi Al-Hadhoroh Al-Islami. Cet-I. Beirut. Dar Asy-Syuruq.

Iman, Nofie. 2008. Panduan Singkat dan Praktis Memulai Investasi Reksa Dana. Jakarta. Kompas Gramedia.

Ismail. 2011. Perbankan Syariah. Cet-I. Jakarta. Prenada Media Group.

Iswandoro. 1999. Uang dan Bank. Cet-6. Yogyakarta. BPFE.

Kuncoro, Mudrajat. 2002. Manajemen Perbankan Teori dan Aplikasi. Cet-I. Yogyakarta. BPFE.

Lewis, Mervyn K. 2007. Perbankan Syariah. terj. Burhan Subrata. Cet-I. Jakarta. PT Serambi Ilmu Semesta

Machmud, Amir. 2010. Bank Syariah. Jakarta. Erlangga.

Martono. 2007. Bank dan Lembaga Keuangan Lain. Cet-4.Yogyakarta. Ekonisia.

Nasarudin, M. Irsan. 2011. Aspek Hukum Pasar Modal Indonesia. Cet-7. Jakarta. Prenada Media Group.

Nazir, Moh. 2009. Metode Penelitian. Jakarta. Ghalia Indonesia.

Pasal 1 Undang-Undang Republik Indonesia No. 10 Tahun 1998 Tentang Perubahan atas Undang-Undang No. 7 Tahun 1992 Tentang Perbankan, www.hukumonline.com, diakses pada 2 Oktober 2017, pukul 12:04

Pasal 1 Undang-undang No. 21 Tahun 2008 tentang Perbankan Syariah, www.hukumonline.com, diakses pada tanggal 2 Oktober 2017 pukul $11: 58$

Qal'ah Jai, Muhammad Rawwas. 2001. Mausu'ah fiqhi Ibnu Taimiyyah. Cet-II. Beirut. Dar An-Nafaes.)

Rifadin, "Tinjauan Deskriptif Sistem Pembagian Hasil Bank Syariah dengan Bank Konvensional", Jurnal Eksis, Politeknik Negeri Samarinda, Vol. 6, No.1, Maret 2010: 1267-1266

Sa'id, Muhammad Ra'fah. 2002 . 'Aqdu Al-Istishna' wa 'Alaqatihi bi Al-'Uqud Al-Jaizah. Cet-I. Dar-Al-Wafa'.

Sabiq, Sayyid. Fiqih Sunnah. Kairo. Al-Fathu Lili'lam Al-Arabi.

Santi, Mei. "Bank Konvensional vs Bank Syari'ah", Jurnal Eksyar, STAI Muhammadiyah Tulung Agung, Vol. 02, No. 01, Juni 2015: 222-243

Soemitra, Andri. 2015. Bank dan Lembaga Keuangan Syariah. Cet-5. Jakarta. Prenadamedia Group.

Sudarsono, Heri. 2003. Bank dan Lembaga Keuangan Syariah. Edisi 2. Yogyakarta. Ekonosia. 
Sula, Muhammad Syukir. 2004. Asuransi Syariah. Jakarta. Gema Insani Press. Sumiyanto, Ahmad. 2008. BMT Menuju Koperasi Modern. Yogyakarta. ISES Publishing.

Wizaratu Al-Awqaf wa Asy-Syu'un Al-Islamiyyah. 1983. Al-Mausu'ah AlFiqhiyyah. Cet-I. Kuwait. Dar Ash-Shafwah.

Zaid, Muhammad Abdul Aziz Hasan. 1996. At-Tathbiq Al-Mu'ashir Li 'Aqdi AsSalam. Cet I. Kairo. Al-Ma'had Al-'Alami Lilfikri Al-Islami.

Zuhaili, Wahbah. 2002. Al-Muamalat Al-Maliyah Al-Mu'ashiroh. Beirut. Dar Al-Fikr.

Zuhaili, Wahbah. 1985. Fiqh Al-Islam wa Adillatuhu. Cet-II. Damaskus. Dar AlFikr.

Zulhendry. 2013. Operasional Bank. Yogyakarta. Andi Offset. 
